\title{
Integration: twelve propositions after Schinkel
}

\author{
Adrian Favell
}

Correspondence: A.Favell@leeds.ac uk; http://www.adrianfavell.com University of Leeds, Leeds, UK

\begin{abstract}
By way of a commentary on Willem Schinkel's 'Against "immigrant integration": For an end to neocolonial knowledge production' in this volume, I propose twelve propositions in order to rethink the academic use of the concept "integration" in contemporary migration studies. The notion of "immigration integration" is deeply embedded in a methodological nationalism found throughout mainstream research and policy making on "immigration" that reproduces a colonial, nation-state centred vision of society sustained by global inequalities. The article broadly shares Schinkel's arguments, while suggesting specific operationalisations which could advance a more autonomous social scientific understanding of how the categorisation of international migration and mobilities is used by nation-states to sustain particular orders and hierarchies of social power.
\end{abstract}

Keywords: Integration, Assimilation, Immigration, Immigrants, Methodological nationalism

It is not difficult for me to write a commentary on Schinkel's text 'Against "immigrant integration"' (Schinkel, 2018). Although I might quibble about some of the philosophical stylisms, I basically agree with his arguments. As I have written in response to his brilliant 2017 work (Schinkel, 2017; see also Schinkel, 2013), Imagined Societies: A Critique of Immigrant Integration in Western Europe: "Mainstream approaches to immigration continue to blindly reproduce the language and logic of nationalist politicsespecially with the notion of immigrant "integration", a hugely problematic concept that that has barely ever been examined critically. Referring to, but ranging well beyond, the crucial case of the Netherlands, Willem Schinkel's trenchant book lays out new avenues of critical thought in migration studies, which expose the mechanics, assumptions and damaging cooption involved in far too much policy related social science in this field." The challenge here is how to move this agenda out of the somewhat comfortable terrain of critical race and whiteness studies-and their allied fields in critical theory, feminist theory and so on-into the heartland of applied comparative empirical work.

The deconstruction of the mainstream on its own terms will be no easy task. Partly because alternate critical approaches have found their own safe spaces, networks and career paths in academia, I have little faith in the long run exposure of the "theoretical hiccup" Schinkel dissects. Academics across epistemologies simply don't talk to each other-because they have no need to. Meanwhile "multiculturealism", as he describes it-basically a reactionary, neoconservative nationalism-has everywhere in Europe

(C) The Author(s). 2019 Open Access This article is distributed under the terms of the Creative Commons Attribution 4.0 International License (http://creativecommons.org/licenses/by/4.0/), which permits unrestricted use, distribution, and reproduction in any medium, provided you give appropriate credit to the original author(s) and the source, provide a link to the Creative Commons license, and indicate if changes were made. 
triumphed as a default common sense: in the UK it is personified in the massive, best-selling impact of Collier (2013) and Goodhart (2013). And this populist triumph is abetted as Schinkel also pungently reveals, by a much more serious and worthy comparative social science of immigrant integration, that reacts with anger and dismissal when its own non-reflexive, methodological nationalist assumptions and implications are exposed (Alba \& Foner, 2016, responding to Favell, 2016, a critique of Alba \& Foner, 2015).

But we get nowhere in social science without operationalisation. And so my contribution here is to try to work through a stepwise rationale of operationalisation that might take us some way towards the de-colonial social science that Schinkel evokes, but which is not necessarily best served by the most powerful versions of critical migration studies on offer. One might say: after Schinkel, or indeed after many of the various critical writings in a similar post-Marxist/Foucauldian and/or de-colonial vein, such as Anderson (2013), de Genova (2010), Mezzadra and Neilson (2013), or McNevin (2011)... What then? As with Schinkel, I would assume as a starting point a familiarity with the state-of-the-art mainstream comparative work, Strangers No More: Immigration and the Challenges of Integration in North America and Western Europe, by Alba and Foner (2015).

1. The move from assimilation to integration (as in Alba and Foner) is a retrogressive and ingenuous one-it solves nothing. Most seriously operationalised integration measures are in fact assimilation measures. The other main type are dissimilarity indexes. The terms are interchangeable. Whether you call it "assimilation" or "integration", the fundamental question-integration of whom into what?-is not resolved. Research is torn between models of statistical "mainstreams" and constructed categorical "race" comparator groups. The mainstreaming ("colour-blind") model is ascendent in European research influenced by dominant North American models (Alba \& Foner, 2015; Alba \& Nee, 2003); in the US, race-based (segmented) assimilation is still more accentuated (Portes \& Rumbaut, 2001; Portes \& Zhou, 1993). British integration / race inequalities research is a peculiar hybrid (Demireva \& Heath, 2017; Heath \& Cheung, 2007; Khan, Finney, \& Lymperopoulou, 2014; Modood et al., 1997); hybridity is also evident in recent French and Dutch work (Crul, 2015; Kesler \& Safi, 2011; Safi \& Simon, 2013).

2. Integration is a concept not a metaphor. Metaphorical uses should not be acceptable in operational sociological work. If its "insertion" or "inclusion" or "adaptation"-and you want less theoretical baggage (or indeed to simply practice atheoretical descriptive social statistics) - then please call it "insertion" or "inclusion" or "adaptation", not "integration". Many uses of the term "integration" among mainstream sociologists - an example being describing convergent rates of employment of a white majority group and immigrant minority ethnic groups as "economic integration" (as in Demireva \& Heath, 2017) - are strictly atheoretical. At some point, though, we do need a theory of society if we want to actually do sociology as opposed to social statistics (as any German sociologist will tell you). Integration is a full blown theoretical concept. And it is a Durkheimian functionalist concept, so it cannot be meaningfully used outside of this kind of theoretical machinery. Integration implies a bounded system (differentiating itself from its environment); internal differentiation (i.e., division of labour); order (equilibrium) and abstracted values, specific (and differentiated) to that system; internal, progressive, organic complexity, leading to increased 
differentiation of the individual, as an autonomous subject. Basically, it is (just) modernisation theory. If Luhmann (as Schinkel proposes) is too much of a headache, think Meyer (2010). It follows also that it is meaningless to suggested "integration" is a property of any one individual; as in: "this immigrant is more or less integrated". Integration is a property of a social system. Its smallest possible variant is a system of two individuals interacting. Integration, in the classic Durkheimian frame, is what produces the (free) individual.

3. If it is used at all "integration" now today would have to be global (or better: planetary) integration. The idea of national integration is an absurd anachronism. It is amazing that we still have to say this in the social sciences. Have the global studies of the last 25 years taught us nothing in "immigration studies"? Did nothing "international" happen in the twentieth century? Did the complex world systems of industrialisation and colonialism not happen? Historians will all tell us that "national integration" never really happened as it was "imagined"; and if it did it was only ever in the context of (global) industrialisation and colonial exploitation. Economic, cultural, social "integration" at the bounded national level evidently is a conceptual nonsense. The illusion of self-defining nation-state societies is today only sustained because of American hegemony: the last container nation-state, the archetype on which all other nation-state societies consciously or not project their identities. Residual national integrationist thinking is driven by the theory of American society: a curiously Parsonian residue in contemporary sociology. Notwithstanding, in Europe, national integration is blatantly a fantasy of late nineteenth century nationalism, at best only conceivable as a certain illusory image of the container national (Marshallian) welfare state of the 1950s. It was in the case of Britain and France a "post-colonial" fantasy - of withdrawing back into a Wilsonian national territorial state which never existed - because above all these "nations" were - and still are to some extent - "empires". Clearly the modern world system in a Wallersteinian sense is very far from integrated, but there are aspects of integration we can talk about in terms of regionalism, international organisations, international political economy, transnational networks, institutional isomorphism, cultural globalisation, ongoing colonial formations, etc. That's just global studies, business as usual. But it is more than a little bit bizarre that migration studies-the study of human spatial mobilities in a global context-has no central place in this, because of how it is dominantly practiced-as a nation-state-centered obsession with immigrants, national politics and national integration. Of course, this is the standard transnationalist position on methodological nationalism (Wimmer \& Glick, 2002). But what Wimmer and Glick Schiller neglected, and which has been sorely lacking, is further critical work on the master concept of societal integration. This was work begun in the late 1990s by Bommes $(1998,2012)$, and which I attempted to re-frame reflexively in the post-doctoral phase of my early work (from Favell, 1998 to Favell, 2001, 2003). One might also trace the theoretical influences here in Luhmann and Bourdieu, or cite Sayad (1996). And we now clearly have a lot of works amassing at the fringes of the field, not least Schinkel's, which share similar sources (i.e., see also Bauböck, 1994a; Crul \& Schneider, 2010; Dahinden, 2016; Fox \& Mogilnicka, 2019; Grzymala-Kaslowska \& Phillimore, 2017; Korteweg, 2017; Simon, 2005; Valluvan, 2017; and surveys of integration research and policy in Scholten, Entzinger, Penninx, \& Verbeek, 2015; Simon, Piché, \& Amélie, 2015; and my Favell, 2015, a revision and update of the original 2001 Carnegie report first presented in 1999). 
4. Any residual talk today of "national integration" - particularly of the integration of "immigrants" into given "national" societies - is therefore normative not analytical or empirical sociology. It is not an autonomous "scientific" discourse; it is a form of thinking-for-the-state. We may also call it "power-knowledge" as Schinkel says. This mode of thinking focuses attention on the organisation / governance of society, seeking to re-imagine and represent the reality of global society in terms of a national model of politics sustained by national institutions and national citizens (you don't just become an individual, you become a fully empowered moral/political citizen). In this sense, academic researchers working with the national integration paradigm are straightforwardly handmaidens to a political process; their research, again echoing Schinkel, is obviously a form of bio-politics (see Tyler, 2010), reflecting everyday political presuppositions (politicians, policy makers, the media, everyday culture, all reflect this-what I referred to as "public philosophies" in Favell, 1998). Policy oriented "impact" based research has no problem with this form of knowledge/power (or "policy habitus", Scholten, Entzinger, Penninx, \& Verbeek, 2015 quoting Favell, 2001), but credible, critical "autonomous" academic sociologists should. Policy academics may argue that their work is feeding into public discourse, knowledge influencing politics, etc. We do have good examples of "global" and "regional" power-knowledge: the multilevelled expert governance of the EU or UN are examples. But the common-sense power of such concepts as "integration"-and the kind of "society" thus imagined-indicates the re-ascendant political form today, in our post-global era: the National. The form that this power to represent reality in social scientific terms takes dominantly is still nakedly one of political sovereignty in the service of the Prince and Leviathan-basically Hobbesian (cf. Latour, 2006). The justificatory form this dominantly takes in the modern world is of course "Democracy". The idea that the People can determine the Nation as a political unit of governance: impose this representation on international society. Fundamentally, given global mobilities, this involves the canonical state-sovereignty constituting act of identifying "nationals" and "foreigners" among populations within, at, or outside, its borders. Brexit is a nice case study (Favell \& Barbulescu, 2018). In the unfinished global society of the 1990s and 2000s, of course, what is striking is how this notion of the political/democratic became unmoored from other forms and scales of societal integration - economy, culture, social relations, human geographies, and increasingly all scientific accounts of these global systems. Transnational citizenship / post-national membership is an entirely unresolved but still vital conundrum (Bauböck, 1994b; Jacobson, 1996; Soysal, 1994); social science today is pedalling backwards in its normative thinking on this (although see Soysal, 2012).

5. Integration is not always desirable. Truly integrated national societies might look like North Korea or East Germany under Honecker. Full integration implies rigidity, conformity, fixed differentiations, and closure. If we want to be normative with our science, we clearly don't have a clear normative measure at all of what a "good" integration looks like, given obvious trades off with freedom/individuality (vrs free riding etc) on the one hand, and decolonial/Foucauldian critiques of assimilation into modernity (of "whiteness") on the other (the Schinkel line). Immigrants may be subjected to too much integration. Yes, invisibility is generally the endpoint, but that has little to do with being a national. A lot of celebrations of "successful" integration are celebrations of class inequalities-how wonderful it is that black people have attained the modest success of white "national" working classes, etc. 
6. The myth of national integration is of course an alignment of the individual with the norms (the "mean") of mainstream society. And the operationalisation works (up to a point) with aggregates and behavioural measures. But no structural assimilation (which is all that is) can work without values and culture aligning too-citizenship proprement dit. This requires cognitive ability, knowledge, self-awareness, and ultimately proof of one's autonomy as a moral individual. All integration tests have involved this kind of material-it is what you can examine an individual on; on how they have been socialised, and become independent. But of course once the focus is no longer behavioural it is no longer focusing on a body in space and time (which may be territorialised), but a mind that is made up of vast lexicon of components of thinking, feeling, saying and imagining, that of course are made up of all the world in some way; even a stereotypical "left behind" white working class UKIP English voter in Grimsby, Lincolnshire has seen American television (see Aksoy \& Robins, 2008 on "banal transnationalism"). The State of course has every interest of penetrating as far as it can in the psyche-the national is the means to do this, integration is the way the State thinks.

7. If we were to use integration as a sociological concept, it should rather be a measurement of the de-differentiation of the "national" by the "foreign" (in the shape of the foreigner). Immigration policy does the opposite: it is how nation-states keep themselves apart from the world (Waldinger, 2015). What they call "integration" in fact is a measure of how successfully they differentiate the national society from its wider anchorings. An inverted use of dissimilarity indexes here might be a useful way of getting at the genuinely post-national intuition that lies at the heart of research on superdiversity (to query for a moment Schinkel's swift dismissal of this field of workwhich has been led by anthropologists).

8. But: Integration into what? The quintessense of integration would be the construction of the translucent (modern, global) individual: it would (still) be the individual, the self, the free soul, the person able to be different not the same; empowerment, individuality, autonomy etc; i.e. (just) centuries of philosophy of the subject. It is also quite simply the "world citizen" predicated as the outcome of nearly all national "internationalised" educational policies in developed and developing countries around the world (Schissler \& Soysal, 2005, in the world sociology tradition of Meyer). The critique of methodological whiteness, of course, comes next. The point is, though, that that critique has to be empirical one: yes, access to Meyer's world is $o b$ servably differentiated by race, class, gender, culture (ethnicity), disability-all the standard stuff sociologists write about. In other words, assimilation can and should be modelled (critically) as assimilation into "whiteness"-into Modernity (as such)-becoming a translucent modern individual (although often the same thing in some contexts, to avoid the confusion where "white/whiteness" no longer always refers to skin-colour, I would say "translucent" is the general form modern invisibility now takes). But this process is of course (empirically) classed, raced, gendered, able-bodied, etc. My point is that there is an intersection here where (planetary) assimilationist and (i.e.) critical race studies or Foucauldian readings are compatible (if they differ, it would be for normative reasons centred on differing understandings of Kantian autonomy and Foucault's "What is Enlightenment?"). A well "integrated" modern person is not one who is attaining norms of working class attainment! How ridiculous. Are you 
"integrated" as soon as you cross a poverty subsisdence line? Attain an average wage? Become "middle class"? When you are no longer a visible social "problem" (as a group)? No wonder a lot of scholars (as well as Schinkel) find this offensive (he labels it "racist"). We agree: national integration imagined and projected with such threshold criteria onto immigrants is of course automatically a form of subordination/domination vis-à-vis truly translucent modern individuals. Usually national integration not only compares them to "losers" of this system; it also "groups" them (usually by the concept of "ethnicity") so as to prevent or make difficult any individual differentiation. Any kind of measurement of attainment vis-à-vis a "national mainstream" will inevitably smuggle in with it "cultural" markers of attainment that are no longer required of translucent global individuals, who by definition have an à la carte relation to the national cultural requirements which need to be plebiscited ("democratically") every day, in the old republican terms of Renan-and which are imposed on newcomers in the society so that they must prove they belong (i.e., in conditional integration "tests"). The idea here is that you only become a "neoliberal" subjectivity beyond a certain wage/affluence/education criteria. Class and race/immigrant domination are therefore substantially the same thing. If national acculturation were not à la carte for those who consider themselves "the free", modern life would be totally unbearable (the dilemma of Orwellian/Foucauldian governmentality; see Favell, 2018). Of course, some migrants have social trajectories that take them into the global social classes of modernity; indeed some were already born into it (there is a small \%, even in some very poor countries). Race, gender, culture, disability cannot account for all disadvantage in the stratified production of "world citizens". That in itself is not surprising. But- and this is the key step empirically-it is the probable disadvantage of the low value nationality with which they were born which matters most, not their lucky global elite status. This is what global inequalities and birthright scholars theorise in terms of life chances according to national birthright and the index value of nationality (Kochenov, 2016; Milanovic, 2010; Shachar, 2009).

9. Global inequalities and the birthright lottery make the stark point that regardless of a putative global citizenry (which in any case is mostly derived from nationality), one's nationality at birth may account for as much as $80 \%$ of life chances. Race, gender, culture, disability (etc) may have more local or contextual effects on differentiation, but the big picture of absolute inequalities is always the difference between being born in the US with American citizenship or being born in Somalia with Somalian citizenship, regardless of race, gender, culture, disability (etc). Trump's policy made this point literally with his Muslim travel ban on eight nationalities regardless of socio-economic class status. National integration policy is premissed on the idea that the long and winding road to becoming a successful, "good" UK citizen is in the end proof that British citizens, born and bred, did indeed win the lottery of life, and no matter where they were born in the national hierarchy (as they so much like to think): i.e., it is how it gets them to suspend their judgement on where they fall within the distribution of UK nationals (as long as they can value their nationality by knowing that others do not have it). This is perhaps why the popular resistance led by the likes of Collier and Goodhart is so much against the hollowing out of national citizenship-even as they accept an ever narrowing, ever more governmental, "moral" criteria for who is a "good" citizen and a legitimate part of the national "community of value" (Anderson, 2013). 
10. Any concern with integration that wants to transcend this naked form of (colonial) nationalism must therefore take as its priority the effect on global inequalities that are structured by inequalities of nationality-integration of immigrants in the conventional sense basically exacerbates this when it ignores it, or assumes redistributional benefits beyond the nation-centred model. The point of course is one from the transnationalism and free movement/development literatures-but it eschews the optimistic promoters of second generation transnationalism who tried to claim that transnationalism was compatible with national integration (Levitt \& Glick, 2004; see also similar arguments in Erdal \& Oeppen, 2013, Faist, 2008, Snel, Engbersen, \& Leerkes, 2006, Trenz \& Triandafyllidou, 2017-all of these works fail to define "integration" outside of the national paradigm, as well as evacuating integration processes of the inevitable coercion and domination involved, on both counts reproducing "methodological nationalism" despite themselves). How could it be compatible? No; because of global inequalities and the indexical value of nationality, there clearly is a negative trade off between becoming an nationalised American and being a transnational Mexican. That kind of relation can be positive when there is no border. But when there is a border, as there always is to some extent, and particularly when the State is engaged in strenghtening the border (hence the valuation of nationals vrs foreigners), the relation becomes increasingly negative (cf. Waldinger, 2015). This kind of question and its change over time can be empirically measured.

11. Bordering processes lie centre stage in the production and reproduction of global inequalities. When transnationalism is limited, controlled and governed-as it inevitably is to some degree-then the situation of global inequality is worsened. That is perhaps obvious from the literature on migration and development. But what is perhaps less obvious is that the operation of categorising cross-border transactions, and particular the action of identifying legal and illegal migrants, or distinguishing between wanted/unwanted migration, and imposing integration on a ever-shrinking number of recognised "good" immigrants, is itself how the nation resists development for others, re-producing itself and its colonial relations with the rest of the planet (see also Anderson, 2013). It is the point at which the happy mutualist utopia of The Wealth of Nations is transformed into something else: the mercantillist political economy of global colonialism. It is the very source of the national power of state-making. Increasingly in a global and porous world this action of bordering is how state (political) power is generated from cross-border mobilities, otherwise known (in neo-liberal terms) as the free movement of capital, goods, services and persons. Here of couse, we enter an interesting debate with (Italian) Marxists who see bordering as a prodution essential to neo-liberal capitalism rather than/as well as nationalist state power (cf. Mezzadra \& Neilson, 2013; or, also influenced by Agamben, de Genova, 2010).

12. Political power flows from the successful imposition of migration/population categories on mobilities. It is the heart of sovereignty. The implications of this are huge. It matters greatly how state bordering processes deal with the multiple kinds of mobilities found amidst global integration. What difference do the 35 million tourists annually in London make when they are an unacknowledged part of everyday "national" society? Or the 3+ million EU nationals in the UK who felt a national border crossing them on 24 June 2016-as they became, overnight, coercively designated "immigrants" in a land where they had been simply "free moving" residents in one part of 
the EU? What difference does it make if migrants crossing are only a small \% of all daily crossings of the Mexican/US border? When "walls" are substantially "smoke and mirrors"? The State/the People has every interest in governing/classifying/controlling everything-even if the irregular/informal is always exceeding it. It helps the State greatly, though, when migration as "immigration" can be separated clearly from the continuum of these other mobilities. Again, mainstream immigration/integration scholars are naive co-producers in this production of power and domination. And it is not a big step to a bigger, second, realisation; that the production of borders internal to the nation-social distinctions-may also be the heart of political power (of governance) as such: the democratic governance of race, ethnicity, culture, gender, disability, even class, through the institutionalised categorical recognition of difference / inequality-i.e., how the State renders its objects and subjects legible for domination (cf. Mann, 1986/1993; Scott, 1998). The nation in the end is the organising unit of democratic political power; its integrating differentiations and its differentiated integration the mode by which the political produces and concentrates, binds and bounds power over the societal in an otherwise global/planetary context. These processes enact in multiple ways "nationalised" spheres of state knowledge production, which reinforce and reproduce familiar national indexes, hierarchies and stratifications of social power.

This of course opens the path to a much broader, more systematic account: what I would call the foundational principles of political demography-which underlie political economy and below which lie the principles of political ecology.

A debate to be continued, I hope.

Authors' contributions

The author read and approved the final manuscript.

Competing interests

The author declares that he has no competing interests.

\section{Publisher's Note}

Springer Nature remains neutral with regard to jurisdictional claims in published maps and institutional affiliations.

Received: 30 August 2018 Accepted: 21 October 2018

Published online: 16 May 2019

References

Aksoy, A., \& Robins, K. (2008). Banal transnationalism: The difference television makes (Transnational Communities Working Paper WPTC-02-08). Oxford.

Alba, R., \& Foner, N. (2015). Strangers no more: Immigration and the challenges of integration in North America and Western Europe. Princeton: Princeton University Press.

Alba, R., \& Foner, N. (2016). Strangers no more: A rejoinder. Ethnic and Racial Studies, 39(13), 2361-2369.

Alba, R., \& Nee, V. (2003). Remaking the American mainstream: Assimilation and contemporary immigration. Cambridge: Harvard University Press.

Anderson, B. (2013). Us and them: The dangerous politics of immigration control. Oxford: Oxford University Press.

Bauböck, R. (1994a). The integration of immigrants (CMDG-report). Strasbourg: The Council of Europe. Retrieved from http:// www.forschungsnetzwerk.at/downloadpub/ihsrp_15.pdf.

Bauböck, R. (1994b). Transnational citizenship: Membership and rights in international migration. Aldershot: Edward Elgar.

Bommes, M. (1998, February 16). Migration, nation state and welfare state: A theoretical challenge for sociological migration research. Paper presented at the European forum on migration, EUI, Florence.

Bommes, M. (2012). In C. Boswell, \& G. D'Amato (Eds.), Immigration and social systems: Collected essays of Michael Bommes. Amsterdam: University of Amsterdam Press.

Collier, P. (2013). Exodus: Immigration and multiculturalism in the 21st century. London: Penguin.

Crul, M. (2015). Super-diversity vs. assimilation: How complex diversity in majority-minority cities challenges the assumptions of assimilation. Journal of Ethnic and Migration Studies, 42(1), 54-68.

Crul, M., \& Schneider, J. (2010). Comparative integration context theory: Participation and belonging in new diverse European cities. Ethnic and Racial Studies, 33(7), 1249-1268.

Dahinden, J. (2016). A plea for the 'de-migranticization' of research on migration and integration. Ethnic and Racial Studies, $39(13), 2207-2225$. 
De Genova, N. (2010). The deportation regime: Sovereignty, space and the freedom of movement. In N. De Genova, \& N. Peutz (Eds.), The deportation regime, (pp. 33-65). Durham: Duke University Press.

Demireva, N., \& Heath, A. (2017). Minority embeddedness and economic integration: Is diversity or homogeneity associated with better employment outcomes? Social Inclusion, 5(1), 20-31.

Erdal, M., \& Oeppen, C. (2013). Migrant balancing acts: Understanding the interactions between integration and transnationalism. Journal of Ethnic and Migration Studies, 39(6), 867-884.

Faist, T. (2008). Diversity - A new model of incorporation. Ethnic and Racial Studies, 32(1), 170-191.

Favell, A. (1998). Philosophies of integration: Immigration and the idea of citizenship in France and Britain. London: Palgrave.

Favell, A. (2001). Integration policy and integration research in Western Europe: A review and critique. In T. A. Aleinikoff, \& D. Klusmeyer (Eds.), Citizenship today: Global perspectives and practices, (pp. 349-399). Washington DC: Brookings Institute/ Carnegie Endowment for International Peace.

Favell, A. (2003). Integration nations: The nation-state and research on immigrants in Western Europe. Comparative Social Research, 22, 13-42.

Favell, A. (2015). Integration policy and integration research in Western Europe: A review and critique. In A. Favell (Ed.), Immigration, integration and mobility: New agendas in migration studies 1998-2014, (pp. 69-122). Colchester: ECPR Press.

Favell, A. (2016). Just like the USA? Critical notes on Richard Alba and Nancy Foner's cross-Atlantic research agenda. [Review of the book Strangers no more: Immigration and the challenges of integration in North America and Western Europe, by R. Alba \& N. Foner]. Ethnic and racial studies, 39(13), pp. 2352-2360. https://doi.org/10.1080/01419870.2016.1203447.

Favell, A. (2018). Winning the victory over yourself. Va+ Victory and Artistic Production, (\#5), p. 13. Tokyo: Joshibi University of Art and Design. Retrieved from https://cj-ca.org/2018/03/23/va-issue-005-victory-and-artistic-production/.

Favell, A., \& Barbulescu, R. (2018). Brexit, "immigration" and anti-discrimination. In P. Diamond, P. Nedergaard, \& B. Rosamond (Eds.), The Routledge handbook of the politics of Brexit. London: Routledge.

Fox, J., \& Mogilnicka, M. (2019). Pathological integration, or, how east Europeans use racism to become British. British Journal of Sociology, 70(1), 5-23.

Goodhart, D. (2013). The British dream: Successes and failures of post-war immigration. London: Atlantic.

Grzymala-Kaslowska, A., \& Phillimore, J. (2017). Introduction: Rethinking integration. New perspectives on adaptation and settlement in the era of super-diversity. Journal of Ethnic and Migration Studies. https://doi.org/10.1080/1369183X.2017.1341706.

Heath, A., \& Cheung, S. Y. (Eds.) (2007). Unequal chances: Ethnic minorities in Western labour markets. Oxford: Oxford University Press.

Jacobson, D. (1996). Rights across Borders: Immigration and the decline of citizenship. Baltimore: Johns Hopkins University Press.

Kesler, C., \& Safi, M. (2011). Immigrant/native labor market inequalities: A portrait of patterns and trends in France and the United Kingdom, 1990-2007. (Working Paper No. 2011-01). Retrieved from https://hal-sciencespo.archives-ouvertes.fr/hal00972748/document.

Khan, O., Finney, N., Lymperopoulou, K. (2014). Drifting upwards or sliding back? Ethnic inequalities in local authorities in England and Wales 2001-2011. Runnymede Trust. Retrieved from https://www.runnymedetrust.org/uploads/ Runnymede\%20Ethnic\%20Inequalities\%20Briefing.pdf.

Kochenov, D. (2016). Quality of nationality index. London: Henley and Partners. Retrieved from https://www.nationalityindex.com/.

Korteweg, A. (2017). The failures of "immigrant integration": The gendered racialized production of non-belonging. Migration Studies, 5(3), 428-444.

Latour, B. (2006). Nous n'avons jamais été moderne [We have never been modern]. Paris: La Découverte.

Levitt, P., \& Glick Schiller, N. (2004). Conceptualizing simultaneity: A transnational social field perspective on society. International Migration Review, 38(3), 1002-1039.

Mann, M. (1986/1993). The sources of social power (Vol. 1/2). Cambridge: Cambridge University Press.

McNevin, A. (2011). Contesting citizenship: Irregular migrants and the new frontiers of the political. New York: Columbia University Press.

Meyer, J. W. (2010). World society, institutional theories and the actor. Annual Review of Sociology, 36, 1-20.

Mezzadra, S., \& Neilson, B. (2013). Border as method; or, the Muliplication of labor. Durham: Duke University Press.

Milanovic, B. (2010). The haves and the have nots: A brief and idiosyncratic history of global inequality. New York: Basic Books.

Modood, T., Berthoud, R., Lakey, J., Nazroo, J., Smith, P., Virdee, S., \& Beishon, S. (1997). Ethnic Minorities in Britain: Diversity and Disadvantage (Series: PSI report, No. 843). Policy Studies Institute: London.

Portes, A., \& Rumbaut, R. (2001). Legacies: The story of the immigrant second generation. Berkeley: University of California Press.

Portes, A., \& Zhou, M. (1993). The new second generation: Segmented assimilation and its variants. Annals of the American Academy of Political and Social Sciences, 530, 74-96.

Safi, M., \& Simon, P. (2013). Les discriminations ethniques et raciales dans l'enquête Trajectoires et Origines: représentations, expériences subjectives et situations vécues [Ethnic and racial discrimination in the Trajectories and Origins survey: representations, subjective experiences and real-life situations]. Economie et Statistique, 464-466, 245-275.

Sayad, A. (1996). Immigration and "state thought". In A. Sayad (Ed.), The suffering of the immigrant, (pp. 278-293). Cambridge: Polity Press.

Schinkel, W. (2013). The imagination of "society" in measurements of immigrant integration. Ethnic and Racial Studies, 36(7), $1142-1161$.

Schinkel, W. (2017). Imagined societies: A critique of immigrant integration in Western societies. Cambridge: Cambridge University Press.

Schinkel, W. (2018). Against 'immigrant integration': for an end to neocolonial knowledge production. Comparative Migration Studies, 6. https://doi.org/10.1186/s40878-018-0095-1.

Schissler, H., \& Soysal, Y. N. (2005). The nation, Europe, and the world: Textbooks and curricula in transition. New York: Berghahn.

Scholten, P., Entzinger, H., Penninx, \& Verbeek, S. (Eds.) (2015). Integrating immigrants in Europe: Research policy dialogues. Springer International Publishing. Retrieved from https://www.springer.com/gp/book/9783319162553.

Scott, J. C. (1998). Seeing like a state: How certain schemes to improve the human condition have failed. New Haven: Yale University Press.

Shachar, A. (2009). The birthright lottery: Citizenship and global inequality. Cambridge: Harvard University Press.

Simon, P. (2005). The measurement of racial discrimination: The policy use of statistics. International Journal of Social Science, 183, 9-25. 
Simon, P., Piché, V., \& Amélie A. (Eds.). (2015). Social statistics and ethnic diversity: Cross-National Perspectives in classification and identity politics. Springer International Publishing. Retrieved from https://www.springer.com/gp/book/ 9783319200941\#aboutBook.

Snel, E., Engbersen, G., \& Leerkes, A. (2006). Transnational involvement and social integration. Global Networks, 6, 285-308. Soysal, Y. N. (1994). Limits of citizenship: Migrants and post-National Membership in Europe. Chicago: Chicago University Press. Soysal, Y. N. (2012). Citizenship, immigration and the European social project: Rights and obligations of individuality. British Journal of Sociology, 63(1), 1-21.

Trenz, H.-J., \& Triandafyllidou, A. (2017). Complex and dynamic integration processes in Europe: Intra EU mobility and international migration in times of recession. Journal of Ethnic and Migration Studies, 43, 546-559.

Tyler, I. (2010). Designed to fail: A biopolitics of British citizenship. Citizenship Studies, 14(1), 61-74.

Valluvan, S. (2017). Racial entanglements and sociological confusions: Repudiating the rehabilitation of integration. British Journal of Sociology, 39(2), 436-58.

Waldinger, R. (2015). The cross-border connection: Immigrants, emigrants and their homelands. Cambridge: Harvard University Press.

Wimmer, A., \& Glick Schiller, N. (2002). Methodological nationalism and beyond: Nation-state building, migration and the social sciences. Global Networks, 2(4), 301-334.

Submit your manuscript to a SpringerOpen ${ }^{\circ}$ journal and benefit from:

- Convenient online submission

- Rigorous peer review

- Open access: articles freely available online

- High visibility within the field

- Retaining the copyright to your article

Submit your next manuscript at $\boldsymbol{\nabla}$ springeropen.com 